\title{
The Occurrence of a Myoblastic Form of Muscle in the Sinus Venosus of the Adult Goldfish (Carassius auratus )
}

Muscle of adult vertebrates is generally considered to be of two forms, smooth or striated, the myoblastic form appears to be restricted to the embryonic vertebrate, except in pathological cases ${ }^{1}$. However, during work in the ultimobranchial gland of fish, it was observed that a cell-type existed in the wall of the sinus venosus of the goldfish which was uninucleate, spindle-shaped, rich in cytoplasm and cytoplasmic inclusions, but in which were contained striated myofibrils.

The sinus venosus is known to be a thin wall of a slightly contractile element of the teleost heart. Although it is also known that heart-muscle continues into the sinus venosus ${ }^{2}$, we have been unable to find a specific description of its form.

Light-microscopy of the wall of the sinus venosus of $10-15 \mathrm{~cm}$ long goldfish, fixed in Bouin, and stained with iron-haemotoxylin and Orange $G$ revealed, at the periphery of the wall, cells which have the appearance of myoblasts with myofibrils ${ }^{3}$. This is seen in Figure 1. The fibrils appear to be about $20 \mu \mathrm{m}$ in length. The fibrils do not appear to be of the Purkinje type, for they

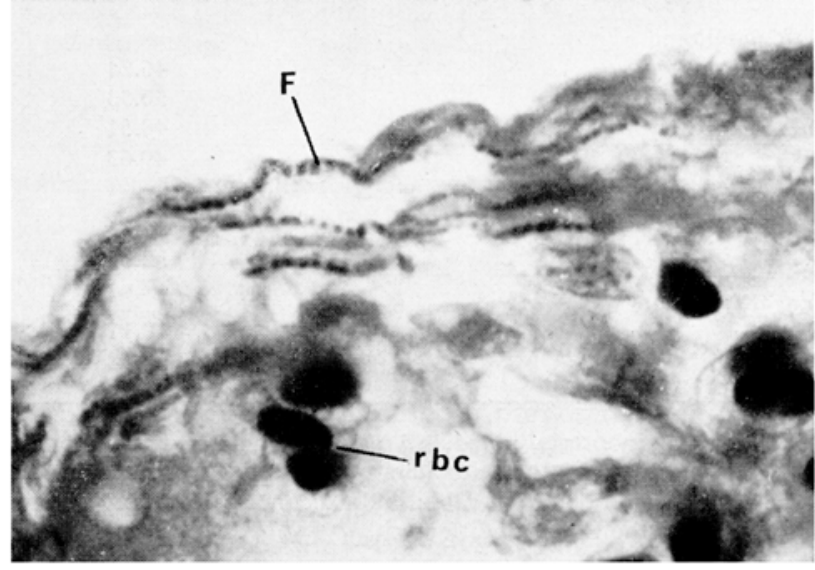

Fig. 1 (light microscope). Sinus venosus wall. F, fibril; rbc, red blood corpuscle. $\times 1650$.

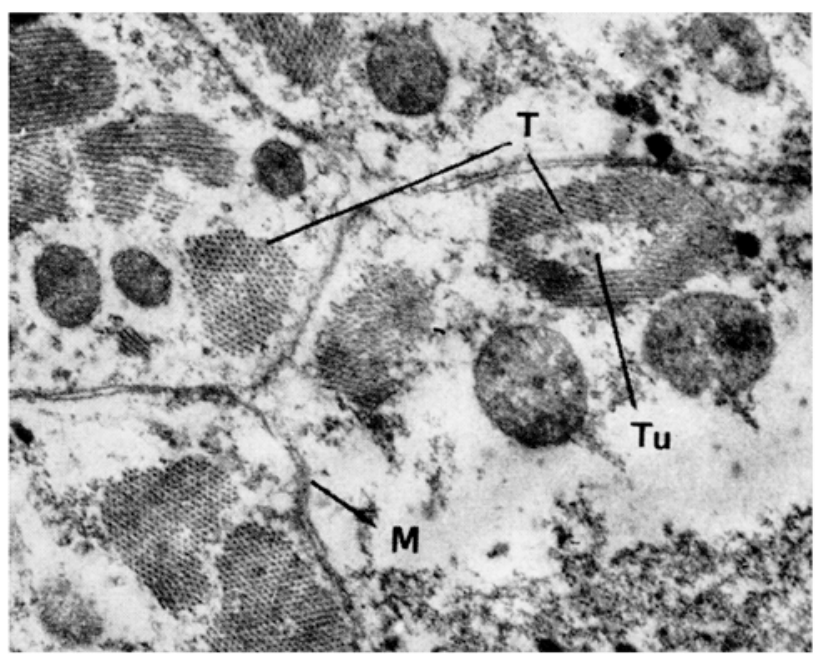

Fig. 2 (electron microscope). $T$, transverse section of fibril; $T u$, tubule; $M$, cell membrane. $\times 20,000$. show no large central vacuole nor is the sarcoplasm divided in separate sections. Close examination of serial sections clearly establishes that the cells are uninucleate, a fact confirmed by electron microscope investigation.

Electron-micrographs of the fibrils show them to have the conventional structure of striated muscle fibres and a diameter of 1-2 $\mu \mathrm{m}$ (Figures 2 and 3). The orientation of the fibrils is seen to be in all directions. The striation of the fibrils appears to be normal; the length of the sacromere being about $2.5 \mu \mathrm{m}$. Tubules are seen, but much more rarely than are observed during the histogenesis of normal striated muscle. The cytoplasm of these cells is characterized by the presence of 2 types of osmophilic granules: 1. smaller granules, which appear in clusters, diameter $20 \mathrm{~nm}$, and 2. larger granules, diameter $250 \mathrm{~nm}$ (Figure 3). Otherwise the cytoplasm, the cell organelles and the nucleus have the conventional appearance of the normal cell. In conclusion, the cell appears to be the form of the muscle of the sinus venosus in a teleost fish.

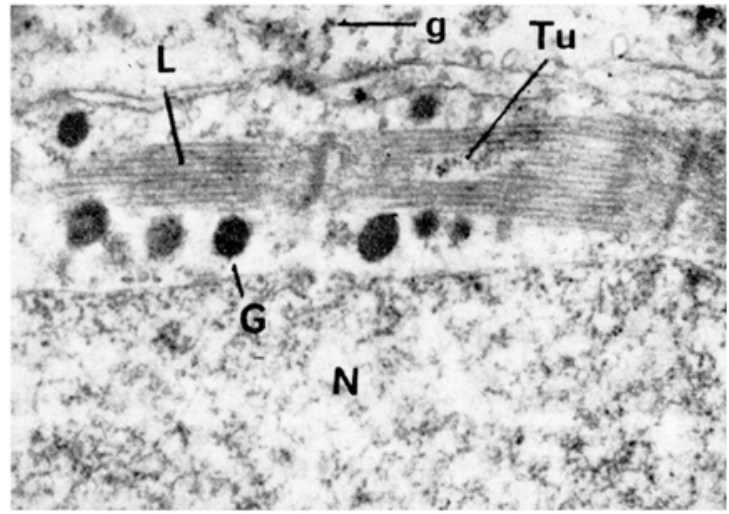

Fig. 3 (electron microscope). L, longitudinal section of fibril; Tu, tubule; G, larger osmophilic granules; N, part of nucleus; $\mathrm{g}$, small osmophilic granules. $\times 20,000$.

Zusammenfassung. Eine licht- und elektronenmikroskopische Untersuchung von Sinus venosus des erwachsenen Goldfisches (Carassius auratus) zeigte eine myoblastische Form von spindelförmigen Zellen, welche quergestreifte Fibrillenm und ausserde eine grosse Anzahl globulärer Teilchen enthielten.

\section{A. J. Matty and K. Deutsch}

Department of Biological Sciences, The University of Aston in Birmingham, Aston, Birmingham 4 (England), and Department of Biology. Thames Polytechnic, London S.E. 18 (England), 17 September 1970.

1 J. T. DONE and K. Devrsck, in preparation.

2 L. Bolk, E. Göppert, E. Kallus and W. Lubosch, in Handbuch der vergleichenden Anatomie der Wirbeltiere (Ascher, Amsterdam 1967), vol. 4, p. 379.

8 G. D. Boyd, in Bourne, Structure and Function of Muscle (Academic Press, London, (1960), vol. 1, p. 74 and 79. 